\title{
WITHOUT RECOURSE TO THE GRIEVANCE PROCEDURE: THE ALBERTA COURTS INVITE MORE LEGAL PROBLEMS
}

\author{
IAN B. McKENNA*
}

This note follows up on Professor McKenna's article on "Restricted Access to Arbitral Review of Dismissal" published last year in this journal. He examines a number of court decisions made since the earlier article was published, particularly the Alberta Court of Appeal decision in the Lethbridge Community College case. These decisions reinforce his concerns about attempts 10 deny employees access to grievance procedures.
La présente note fait suite d l'article du professeur McKenna intitule «Restricted Access to Arbitral Review of Dismissal", publié par notre revue l'année dernière. Il examine un certain nombre de décisions prises depuis la parution de l'article, l'arrêt rendu par la cour d'appel de l'Alberta dans la cause du Lethbridge Community College, en particulier, et se dit préoccupé par les tentatives d'interdire l'accès aux procédures de règlement des griefs.

In an earlier article, this author examined critically the courts' approach to collective agreement proposals or articles that seek to deny certain classes of dismissed employee recourse to the grievance or adjudication procedure available to other members of the bargaining unit.' This article examines emerging difficulties that arise from recent Alberta cases on this issue.

First is the Court of Appeal's decision in the Lethbridge Community College ${ }^{2}$ case. The appellate court upheld the judgment of the Court of Queen's Bench to quash the decision of the Public Service Employee Relations Board (PSERB). The PSERB had withheld from interest arbitration the part of the employer's proposal that sought to deny dismissed "unsuitable" probationary, temporary and casual employees access to the adjudication procedure available to other members of the bargaining unit.

Quashing the PSERB's decision, Hutchinson J. stated: ${ }^{3}$

I remain convinced that the employer's proposed articles are terms and conditions of employment...and are not excluded by s.48(2) of the [Public Service Employee Relations] Act.

That reasoning was criticized in my earlier article because it ignored the fact that $s .48(1)$ also provides a ground for withholding a proposal from arbitration. That subsection reads:

any arbitration board may only consider, and any arbitral award may only deal with, those matters that may be included in a collective agreement.

While Stratton J.A. for the Court of Appeal endorsed both the decision and the reasoning of the lower court, his elaboration of an additional ground of decision suggests some tacit anxiety with Hutchinson J.'s reasoning. The appellate court did acknowledge

Associate Professor, Faculty of Management, University of Lethbridge.

28 Alta L. Rev. 899. In this article, such provisions are referred to as "without recourse."

Board of Governors of Lethbridge Community College v. Public Service Employee Relations Board, PSERB Reference No. 140-003-502 (Jan. 1988, unreported), rev'd (1989), 95 A.R. 363 (Q.B.), aff'd (1990), 75 Alta. L.R. (2d) 378 (C.A.). Leave to appeal to the Supreme Court was denied. 
the relevance of s. $48(1)$ as the vehicle by which the PSERB removed the "without recourse" proposals from interest arbitration. However, Stratton J.A. reasoned that, when s. 61 is read in conjunction with s. $63,{ }^{4}$

it seems clear that the intent of the legislature is not to create, as an illegal act, the omission from a collective agreement of certain specified matters but instead, to cure any such omission by prescribing "deemed" provisions.

It is curious that neither the Court of Queen's Bench nor the Court of Appeal paid the slightest attention to the widely held view that adjudicative review of grievances is one of the twin pillars of Canadian labour relations policy. This view was articulated by the British Columbia Labour Relations Board in the Cassiar Asbestos Corporation ${ }^{5}$ case and by Weiler: ${ }^{6}$

If the parties cannot, by their contract, permit the use of a strike to resolve a grievance, then neither can they agree to limit access to the arbitration process to secure a final and binding adjudication of that grievance.

The Court of Appeal's decision raises the question of whether it would view a "strike" bargaining proposal as also giving rise to no "illegal" act." If it did not, one would find it difficult to explain what possible purpose s. 48(1) of the Act might have. Surely a bargaining proposal to permit strikes during the life of the agreement would undermine the entire purpose of the PSERA and must be excluded from interest arbitration by virtue of $\mathrm{s.} 48(1)$.

Yet, if the appellate court ruled a "strike" proposal non-arbitrable by reason of s. 48(1) (as it must surely do), one would be hard put to justify the differential treatment given to the other pillar of Canadian labour relations legislation - the adjudication of grievances. It might be argued that a "strike" proposal should be treated differently from a "without recourse to adjudication" proposal because the PSERA provides a penalty for breach of s. $93(1)^{8}$ (the prohibition of strikes provision), whereas there is no comparable penalty for breach of s. 61. Indeed, the Court of Appeal hinted at this sort of distinction when it stated that the "deemed" provisions written into a collective agreement by s. 63 supported its view that failure to comply with s. 61 gave rise to no "illegal" act and to no non-arbitrable bargaining proposal. The Court of Appeal's reasoning is suspect in light

4. Supra, note 2(c) at 388.

s. Cassiar Asbestos Corporation v. United Steelworkers of America, [1975] 1 C.L.R.B.R. 212 (B.C.L.R.B. case No. 165/74). This doctrine has been confirmed under two amendments of the British Columbia labour relations legislation. See Alcan Smelters and Chemicals Ltd. v. C.A.S.A.W. Local I, B.C.L.R.B. No. $80 / 77$ at 15. Also Re Westfair Foods Ltd. and U.F.C.W. Local 777, 15 L.A.C. (4th) 199.

a. P. Weiler, Grievance Arbitration: A Review of Current Problems, M.A. Hickling, ed. (U.B.C. Inst. of Industrial Relations, June 1977) at 3.

7. The Public Service Employee Relations Act, R.S.A. 1980, c. P-33 [hereinafter PSERA], s. 93(1) prohibits all strikes by employees.

8. S. 95 . 
of the Cassiar doctrine. The presence of a "deemed" provision in s. 63 of the PSERA is surely evidence of the importance of s. 61 , not of its unimportance.

Furthermore, the apparent relegation of s. 61 vis-a-vis s. 93(1) raises a question of its importance in relation to other provisions of the PSERA. For example, the Act mandates criteria to be considered by interest arbitration boards.' Would the Court of Appeal uphold the arbitrability of a bargaining proposal that sought to entrench in the collective agreement an article requiring an interest arbitrator not to consider these criteria in the event of an impasse in negotiating a renewal of the agreement? One would expect not. Similar questions could be raised about bargaining proposals that sought to include a provision that the collective agreement was not binding on one or more of the parties, ${ }^{10}$ bar members of the bargaining unit from seeking decertification in the "open season" before expiry of the collective agreement, ${ }^{1}$ or deny "professional" employees the right to seek exclusion from the bargaining unit in accordance with s. 23 of the Act. It is scarcely credible that the Court of Appeal would allow provisions so clearly contrary to the policy of the PSERA and would not support the PSERB's use of s. 48(1) to exclude them from interest arbitration. Their inclusion in a collective agreement would simply invite complications at the contract administration stage or in other proceedings before the PSERB. Thus it is difficult to see the consistency in the court's hands-off treatment of bargaining proposals contrary to the intent of s. 61 .

The Court of Appeal's unwillingness to uphold the PSERB's approach in Lethbridge Community College is all the more puzzling in light of the experience in British Columbia, where the Cassiar doctrine holds sway. An example of the impact of Cassiar is found in the collective agreement between the Government of British Columbia and the B.C. Government Employees Union, which provides: ${ }^{12}$

A Deputy Minister may reject any probationary employee for just cause. A rejection during probation shall not be considered a dismissal for the purpose of this agreement. The test of just cause shall be a test of suitability of the probationary employee for continued employment in the position to which he/she has been appointed, provided that the factors involved in suitability could reasonably be expected to affect work performance.

Such a provision meets employers' concerns by applying lower standards of review to employees with less than a full seniority rating but does not exclude such employees completely from arbitral review.

The preferability of the British Columbia position is illustrated by a number of recent Alberta cases. In Marriner v. Southern Alberta Institute of Technology, ${ }^{13}$ the Court of

S. 41 of the PSERA specifies that a collective agreement is binding on the employer, the bargaining agent and every employee in the bargaining unit.

Ss. 32 and 33 of the PSERA provide for revocation of bargaining rights in the "open season."

Eight master agreement between the parties dated 25 January 1989, article 10.09 .

(1990), 104 A.R. 349. 
Appeal confirmed, in the context of the PSERA, the Supreme Court of Canada's principle that $^{14}$

labour relations legislation, provides a code governing all aspects of labour relations, and that it would offend the legislative scheme to permit the parties to a collective agreement, or the employees on whose behalf it was negotiated, to have recourse to the ordinary courts which are in the circumstances a duplicative forum to which the legislature has not assigned these tasks.

The Court of Appeal's approach in the Lethbridge Community College case invites the very pursuit of alternative remedies for injustice that gave rise historically to the courts of equity when the common law failed to deliver. Such was the case in Marriner where the grievor notified the Attorney General of Alberta prior to the Appeal Court hearing that he intended to raise an argument under the Charter of Rights and Freedoms. ${ }^{15}$ While such argument did not materialize, and while the Canadian courts have been reluctant to apply the Charter to labour issues, ${ }^{16}$ a case can be made that there is an infringement of s. 15 rights under the Charter when employees are selectively denied access to any adjudicative review of their dismissal.

There may be further pressure on the courts to grant to employees without recourse to adjudication under the collective agreement judicial review of managerial powers of dismissal where such powers are conferred by statute. There is ample authority that statutory power must be exercised in good faith and without arbitrariness or discrimination, ${ }^{17}$ but it is scarcely consistent with the "exclusivity" doctrine that such remedies should have to be sought as an alternative to collective bargaining remedies when British Columbia experience indicates that the latter can be easily accomplished.

A further undesirable consequence of the Alberta courts' approach has been the use of technical legal arguments by classes of employee selectively denied access to adjudication procedures. This is illustrated by the cases of Alberta Union of Provincial Employees $\mathbf{v}$. Alberta $^{18}$ and AUPE (Local 40) v. Mental Health Board of Ponoka. ${ }^{19}$ In the latter, the adjudicator held that the grievor, a probationer, had been terminated without authority on the part of the hospital director. The termination was ruled a nullity, but the adjudicator found that he had no jurisdiction to reinstate the grievor because article 10:01 of the collective agreement barred recourse to the grievance procedure. Quashing the adjudicator's decision, the Court of Appeal ruled that, once the termination was a nullity, the grievor retained his right to grieve pursuant to articles 7:04 and 9 of the collective

St. Anne Nackawic Pulp and Paper Co. v. Canadian Paper Workers Union, Local 219, [1986] 1 S.C.R. 704 at 718-19.

Supra, note 14 at 354.

Illustrated by the Supreme Court of Canada's approach in the "trilogy": Reference re Public Service Employee Relations Act, Labour Relations Act and Police Officers Collective Bargaining Act (1987), 38 D.L.R. (4th) 161; Public Service Alliance of Canada v. The Queen in Right of Canada (1987), 38 D.L.R. (4th) 249; Government of Saskatchewan v. Retail, Wholesale \& Department Store Union, Locals 544, 496, 635 \& 955 (1987), 38 D.L.R. (4th) 277.

E.g. Re Nicholson and Haldimand-Norfolk Police Commissioners (1978), 88 D.L.R. (3d) 671.

(1989), 98 A.R. 73.

8603-0062-AC (Alta. C.A.) [unreported]. 
agreement. The court distinguished the decision in Re Royal Alexandra Hospital, ${ }^{20}$ where it was held that probationary employees had no right to grieve their dismissal. In the Ponoka case, the fact that the purported termination was a nullity left the grievance procedure open to the dismissed employee.

In the AUPE v. Alberta case, a "wage" employee grieved his termination because he was not given written reasons in accordance with article 28.01 of the collective agreement. The agreement excluded "wage" employees from the grievance procedure in respect of termination or dismissal. The union argued that the employer's failure to comply with article 28.01 rendered the termination a nullity and, in light of the Ponoka decision, the grievor remained an employee. It should be noted that the union did not question the merits of the termination, merely the procedural defect of the failure to provide reasons. The grievor argued that without written reasons he had no way of knowing whether the person who terminated his employment possessed the requisite authority.

The Public Service Grievance Appeal Board held that, in this instance, the failure to provide reasons did not render the termination a nullity because the requirement to provide reasons was merely directory, not mandatory. The board held further that, since the grievor had no right to bring a grievance in the case of termination or dismissal, the failure to receive reasons for his termination did not prejudice his rights under the agreement. Accordingly, the board determined that it had no jurisdiction to determine the merits of the grievance.

The Court of Queen's Bench declined to quash the board's decision, appending its own reason that the duty to give reasons under article 28.01 applied to "dismissal" not to "termination." Cooke J. reasoned that, as the grievor had been "terminated" rather than "dismissed," the duty to give reasons under article 28.01 did not apply to him. ${ }^{21}$ Distinguishing the Ponoka case, the Court upheld the board's view that the failure to give reasons did not render the termination a nullity.

One can scarcely fault grievors for resorting to such technical legal points, as they search for some basis for challenging what they perceive to be an unjust dismissal. While such legalism is perhaps an inevitable response to perceived injustice, it is scarcely consistent with effective labour relations and the resolution of industrial conflict on the job-related merits of issues. The Cassiar approach is preferable because it enables dismissals and terminations to be reviewed on their merits, not on the sometimes obscure legal doctrine of jurisdictional error.

While Cooke J. declined to hold the grievor's termination a nullity, he gave an example of circumstances which might give rise to a nullity. ${ }^{22}$ He suggested that a termination in contravention of human rights legislation, being contrary to law, might be an abuse of management authority and a nullity. This raises another possible avenue of legal redress for "wage" employees. If "wage", "casual" or "temporary" employees are predominantly 
female, it may be that the "without recourse to the grievance procedure" provisions have a disproportionate impact on female members of the bargaining unit. On the authority of Alberta Human Rights Commission v. Central Alberta Dairy Pool, ${ }^{23}$ the employer would engage in unlawful sex discrimination if it failed to take reasonable steps to accommodate those to whom the discrimination applied. Accordingly, a "wage" employee dismissed without recourse to the grievance procedure could argue that the dismissal was unlawful and a nullity. The grievor would have to provide evidence of disproportionate impact on the basis of gender, but the union has easy access to such information. ${ }^{24}$

The Court of Appeal's decision in the Lethbridge Community College case holding that failure to comply with s. 61 of the PSERA gives rise to no "illegal" act appeared to dispose of my contention, in the earlier article, that a "without recourse" bargaining proposal is in breach of the union's duty of fair representation and of the employer's duty to bargain in good faith. ${ }^{25}$ However, if "without recourse" proposals are in potential breach of human rights legislation, the "fair representation" and "bargaining in good faith" challenges remain viable.

To conclude, the Court of Appeal's approach in the Lethbridge Community College case represents a lost opportunity. Had it followed the Cassiar approach, it would have gone far towards preventing "without recourse" provisions from ever getting into collective agreements at all. Instead, the court has invited a continuation of technical legal battles on matters of nullity and jurisdictional error, issues quite removed from the merits of human resources and labour relations policy. Furthermore, the court has invited a round of challenges of "without recourse" provisions based on s. 15 of the Charter of Rights and Freedoms; administrative law duties to exercise power in a manner that is nonarbitrary, non-discriminatory and in good faith; and human rights legislative duties not to discriminate on grounds of gender. ${ }^{26}$ These are scarcely satisfactory alternatives to labour relations mechanisms and are inconsistent with the Supreme Court of Canada's declared preference for the exclusivity of labour mechanisms and remedies. ${ }^{27}$

As a final note on the Court of Appeal's judgment, it should be pointed out that the court founded its decision on the view that non-compliance with s. 61 of the PSERA does not give rise to "illegal" conduct or to a non-arbitrable proposal. This does not preclude

24. The Alberta Individual's Rights Protection Act, R.S.A. 1980, c. I-2, s. 7 as amended by the Individual's Rights Amendment Act, S.A. 1985, c. 33 and by S.A. 1990, c. 23 prohibits discrimination in employment on grounds of "gender." The 1990 amendment substituted the term "gender" for "sex". The joint responsibility of management and unions to combat systemic discrimination is affirmed by Arbitrator Munroe in Re B.C. Telephone Co. and T.W.U., 15 L.A.C. (4th) 146 at 152. Supra, note 1, at 917-21.

26. These may be raised at the bargaining stage, in PSERB proceedings on arbitrability, at adjudication or directly with the Alberta Human Rights Commission.

27. This renders all the more curious the Supreme Court of Canada's denial of leave to appeal the Court of Appeal's judgment in the Lethbridge Community College case (April 2, 1991). Not only is the Supreme Court inviting challenges to its "exclusivity" doctrine, it missed the opportunity to make the authoritative choice between the Cassiar approach, followed in British Columbia, and that adopted by the courts of Alberta. 
an adjudicator from accepting jurisdiction in a case in which a "without recourse" clause purports to exclude from adjudication a grievor whom the adjudicator deems to have a substantive right under the collective agreement. One must remember that, under the Toronto Hydro ${ }^{28}$ doctrine, a probationer or temporary employee who may be dismissed or terminated only if deemed by the employer "unsuitable" or "unsatisfactory" ${ }^{29}$ has a substantive right under the collective agreement which must be subject to final and binding dispute settlement. At present, this would appear to be the most helpful approach for dismissed employees confronted with "without recourse" clauses. However, such an approach is rooted in contractual interpretation, not in statutory policy as advocated by this writer.

Re Toronto Hydro-Electric System and Canadian Union of Public Employees, Local 1 (1980), 26 L.A.C. (2d) 434. Approach upheld by the Ontario Court of Appeal in Re Ontario Hydro and Ontario Hydro Employees' Union, Local 1000 (1983), 147 D.L.R. (3d) 210.

29. This author's survey of collective agreements in Alberta indicated that a significant number of "without recourse" clauses purport to exclude adjudication for certain classes of employee who appear to have a substantive right with respect to dismissal or termination. 